\title{
BIOLOGICAL METHOD FOR THE DETOXIFICATION OF SPENT MONOETHANOLAMINE SOLUTIONS
}

\author{
Rapolas Liužinas ${ }^{I}$ \\ Karolis Jankevičius ${ }^{I}$ \\ Mudis Šalkauskas ${ }^{l}$ \\ Regimantas Jakubènas ${ }^{2}$ \\ Algimantas Paškevičius ${ }^{3}$ \\ Mykolas Mikalajūnas ${ }^{4}$ \\ 'Public Establishment "SOIL REMEDIATION TECHNOLOGIES" \\ 'Stock Company AB "ACHEMA" \\ ${ }^{3}$ Institute of Botany \\ ${ }^{4}$ Vilnius Pedagogical University
}

\begin{abstract}
Monoethanolamine (MEA) solutions are widely used in for gas cleaning from carbon dioxide for many industrial purposes. Spent MEA solutions should be properly decontaminated and safely disposed. As these processes proceed at high temperature, the MEA solutions produce and accumulate tars and other degradation products as well as heavy metals from the corroding equipment.

This report presents a biological method for the detoxification of spent MEA solutions. A solution is mixed with soil in order to inoculate aerobic microorganisms decomposing organic substances; and the obtained substrate is spread on a flat and properly hydro-isolated ground. To strengthen the vitality and increase activity of the microorganisms, the substrate is aerated, humidified, fertilized and its $\mathrm{pH}$ is monitored and controlled. When the MEA concentration is reduced, vascular plants (Calamagrostis epigejos, Secale cereale, Salix viminalis) are implanted in the substrate, and their growth concludes the detoxification.
\end{abstract}

Keywords: monoethanolamine (MEA); detoxification; bioremediation; microorganisms; bacteria; yeasts; vascular plants

\section{INTRODUCTION}

Organic amines and especially monoethanolamine (MEA) and its solutions are widely used in gas cleaning from carbon dioxide for many industrial purposes. As these processes proceed at high temperature $\left(>205{ }^{\circ} \mathrm{C}\right)$ in the presence of iron which is a catalyst for many oxidative destruction reactions [1], the MEA solutions produce and accumulate the products of disintegration and tarring as well as heavy metals from the corroding equipment. Such spent MEA $(20 \%)$ solutions contain more than 50 various organic compounds such as ethylene diamines $(38 \%)$, piperazine and its derivatives $(20 \%), 2$-aminoheptan $(5 \%)$, diethanolamine $(4 \%)$, aliphatic hydrocarbons $(1 \%)$, ethers of fatty acids $(1 \%)$ and other organic compounds as well as heavy metals: Fe $(10 \mathrm{~g} / \mathrm{l}), \mathrm{Ni}(4 \mathrm{~g} / \mathrm{l}), \mathrm{Mn}(70 \mathrm{mg} / \mathrm{l}), \mathrm{Zn}(10 \mathrm{mg} / \mathrm{l})$ and other metals in 
small quantities [2]. Therefore spent MEA solutions should be properly decontaminated and safely disposed.

Utilization and detoxification of such solutions is a serious problem. It has been proposed to decompose MEA by oxygen in the presence of iron catalysts [3]. This method does not detoxify other hazardous products in spent MEA solutions. Some inventors propose special filters for cleaning spent MEA solutions from tars and particles [4]. While others suggest using spent MEA solutions for various cleaning formulations [5] or special glue compositions [6]. Such proposals solve the problem only partially, because hazardous heavy metals cannot be detoxified.

A technology that enables to reuse a part of spent MEA solution in the gas cleaning process is more ingenious [7]. According to this proposal water is eliminated from the spent MEA solution by means of a dephlegmator. The condensate, which contains about one percent of MEA, may be used as a surfactant solution. The remaining solution is fractionated into three parts: the first one, which contains $10-15 \%$ of MEA, is returned to distillation, the second one, which contains about $99 \%$ of MEA, may be used as a commercial product and the third one, containing tars and $1-5 \%$ MEA after vacuum distillation and neutralization may be utilized in fur industry as an auxiliary mean for technological fur treatments. The shortcoming of this technology is that not all nitrogen-containing substances are used properly and no detoxification of heavy metals occurs. The method is rather expensive.

\section{OBJECTIVES}

The first research objective was, to examine the toxicity of MEA and tars in spent MEA solutions by using microorganisms and vascular plants. Main task was to evaluate the possibilities for detoxification of spent MEA solutions by means of bioremediation in soil utilizing nitrogen rich organic compounds in spent MEA solutions as fertilizes for aerobic microorganism and vascular plants. In this study the experiments were conducted in laboratory scale in order to estimate advantages and disadvantages of the method for its industrial application.

\section{METHODS}

\subsection{Assessment of MEA toxicity for microorganisms}

Two agar plate methods were used for evaluation of MEA toxicity for various microorganisms.

1. The filter paper disc method in which we used a sterile $\sim 20 \mathrm{~mm}$ paper disc impregnated with a test solution and placed in the agar medium inoculated by a particular microorganism. After three days of incubation in a thermostat at $19 \pm 0.5{ }^{\circ} \mathrm{C}$ the zones surrounding the disc were estimated.

2. In the agar medium a well was made and filled with $0.05 \mathrm{ml}$ of the test solution. After three days of incubation in a thermostat at $19 \pm 0.5{ }^{\circ} \mathrm{C}$ the zones surrounding the well were estimated.

The concentration of microorganisms in $2 \%$ agar was determined by the number of entities in colonies (NEC) before the toxicity experiment and after 4, 14 and 42 days of exposure at a constant humidity $(60 \%)$ and temperature. For micromycetes we used $2 \%$ agar in beer mash. For suspensions and test solution dilution we used a $0.5 \%$ solution of $\mathrm{NaCl}$. The concentration of microorganism in soil was expressed in NEC/g units. 


\subsection{Assessment of MEA toxicity for seed germination and germination energy}

For seed germination test we selected 200 seeds of winter rye "Širvinta" (mass of 1000 seeds $44,2 \mathrm{~g}$ ) and 200 seeds of winter wheat "Duoniai" (mass of 1000 seeds $42,4 \mathrm{~g}$ ). The seeds were washed with distilled water and placed in Petri dishes with fresh test solutions. The energy of germination was determined at room temperature after three days of germination while the number of seeds that germinated was determined after 6 days.

The seeds were exposed to a series of test solutions prepared by diluting of a MEA solution in the following proportions: $1: 1 ; 1: 2 ; 1: 5 ; 1: 10 ; 1: 20 ; 1: 40 ; 1: 60 ; 1: 80 ; 1: 100 ; 1: 120$.

\subsection{Evaluation of the possibilities for $M E A$ tar detoxification}

For bioremediation we prepared a substrate from a humus rich soil ( $\mathrm{pH} 7.3$ ), two kinds of peat $(\mathrm{pH} 3.1)$, peat $(\mathrm{pH} \mathrm{5.5)}$ and sand. The substrates were mixed with spent MEA solutions in proportion: $1: 0 ; 1: 2 ; 1: 5 ; 1: 10 ; 1: 20 ; 1: 40$.

\subsection{Estimation of MEA toxicity}

The toxicity estimated by the number of microorganisms and by germination of seeds in soil substrates with different MEA concentrations. The measurements of the intensity of respiration obtained from the data on the evolved $\mathrm{CO}_{2}$ that was estimated by sorption in $\mathrm{NaOH}$ solution and titration the remaining concentration of alkali by the $\mathrm{HCl}$ standard solution showed the vitality of microorganisms.

\subsection{Influence of inoculation of microorganisms on the speed-up of MEA degradation in soil}

The mixture of MEA and soil substrate in proportion 1:20 was inoculated by suspensions of microorganism $10^{8} \mathrm{NEC} / \mathrm{ml}$. For inoculations the following suspensions were used:

1. Complex mixture of yeasts (Candida lipolytica, Aureobasidium pullans, Geotrichum fermentans, Rodosporidium dioboeatum, Lipomyces tetrasporus);

2. Micromycetes Trichoderma harzianum Ko-2;

3. Complex mixture of yeasts with a Trichoderma harzianum Ko-2.

4.

Survival of microorganisms was checked after $24 \mathrm{~h}$ following the introduction and repeatedly after one and two months of development. $\mathrm{pH}$ and the content of humidity in the substrate were monitored.

\section{RESULTS AND DISCUSSION}

\subsection{Assessment of MEA toxicity for microorganisms}

Three bacteria (Table 1) and five micromycetes (Table 2) strains were used for the assessment of MEA toxicity. Altogether 8 different concentrations of MEA wastes were tested and the results are presented in Table 1 and Table 2. 
Table 1. Sensibility of bacteria to various concentrations of MEA (method of paper discs)

\begin{tabular}{|c|c|c|c|}
\hline \multirow{2}{*}{$\begin{array}{c}\text { Concentration of } \\
\text { MEA \% }\end{array}$} & \multicolumn{3}{|c|}{ Diameter of sterile zones, mm } \\
\cline { 2 - 4 } & Bacillus megaterium & Esherichia coli & Proteus mirabilis \\
\hline 100 & 8 & 10 & 8 \\
\hline 75 & 6 & 6 & 5 \\
\hline 50 & 3 & 4 & 4 \\
\hline 25 & 3 & 2 & 3 \\
\hline 10 & 2 & 0 & 3 \\
\hline 5 & 1 & 0 & 1 \\
\hline 1 & 0 & 0 & 0 \\
\hline 0.1 & 0 & 0 & 0 \\
\hline
\end{tabular}

The bacteria were established to be rather sensitive to MEA tars. The concentrations lower than $1 \%$ is not bactericidal. Escerichia coli was the most sensitive for higher concentrations of MEA among the investigated bacteria - the zone of sterility reached $4-10 \mathrm{~mm}$ for spent solutions of MEA diluted 1:1. But diluted 1:10 solutions did not affect this bacterium. Bacteria Bacillus megaterium and Proteus mirabilis strains did not respond to the concentration as low as $5 \%$ of MEA.

The toxicity test by using the method of wells is more sensitive as the solution diffusion in agar is direct and therefore the sterile zones are wide, but in our investigations both the methods gave comparable results.

Table 2. Sensibility of micromycetes to various concentrations of MEA (method of paper discs)

\begin{tabular}{|c|c|c|c|c|c|}
\hline \multirow{2}{*}{$\begin{array}{c}\text { Concentration } \\
\text { of MEA } \%\end{array}$} & \multicolumn{5}{|c|}{ Diameter of sterile zones, $\mathrm{mm}$} \\
\hline & $\begin{array}{l}\text { Acremonium } \\
\text { roseum }\end{array}$ & $\begin{array}{l}\text { Cladosporium } \\
\text { herbarum }\end{array}$ & $\begin{array}{l}\text { Fusarium } \\
\text { culmorum }\end{array}$ & $\begin{array}{l}\text { Penicilium } \\
\text { expansum }\end{array}$ & $\begin{array}{l}\text { Trichoderma } \\
\text { harzaianum }\end{array}$ \\
\hline 100 & 17 & 12 & 5 & $5+10 *$ & $2+20^{*}$ \\
\hline 75 & 5 & 8 & 2 & $10^{*}$ & $10^{*}$ \\
\hline 50 & 3 & 4 & 0 & $8^{*}$ & $10^{*}$ \\
\hline 25 & 2 & 2 & 0 & $6^{*}$ & $10^{*}$ \\
\hline 10 & 0 & 0 & 0 & $4^{*}$ & $4^{*}$ \\
\hline 5 & 0 & 0 & 0 & $2 *$ & $3^{*}$ \\
\hline 1 & 0 & 0 & 0 & 0 & 0 \\
\hline 0.1 & 0 & 0 & 0 & 0 & 0 \\
\hline
\end{tabular}

\footnotetext{
* Fungistatic effect
}

Toxic effects of MEA on micromycetes are presented in Table 2 and Table 3.

It was established that MEA toxicity for micromycetes is lower than that for bacteria. The most sensible are fungies Acremonium roseum and Cladosporium herbarum, which did not grow in zone $12-17 \mathrm{~mm}$ around the paper disc impregnated by a waste solution of MEA and were sensible to concentrations of $25 \%$ and higher. For such fungi's as Fusarium culmorum, Penicillium expansum and Trichoderma harzianum the fungistatic effect of MEA was checked only for undiluted solutions or at dilution of $75 \%$ and the sterile zones were no more 
than 1-5 mm wide. But the method of wells shows wider zones $(7-20 \mathrm{~mm}$ for undiluted MEA solutions and the fungistatic effect was presented for diluted $5-10 \%$ solutions.

Table 3. Sensibility of microorganisms determined to various concentrations of MEA (method of wells)

\begin{tabular}{|c|c|c|c|c|c|}
\hline \multirow{2}{*}{$\begin{array}{c}\text { Concentration } \\
\text { of MEA } \%\end{array}$} & \multicolumn{5}{|c|}{ Diameter of sterile zones, $\mathrm{mm}$} \\
\hline & $\begin{array}{l}\text { Acremonium } \\
\text { roseum }\end{array}$ & $\begin{array}{c}\text { Cladosporium } \\
\text { herbarum }\end{array}$ & $\begin{array}{l}\text { Fusarium } \\
\text { culmorum }\end{array}$ & $\begin{array}{l}\text { Penicilium } \\
\text { expansum }\end{array}$ & $\begin{array}{l}\text { Trichoderma } \\
\text { harzaianum }\end{array}$ \\
\hline 100 & 20 & 15 & 7 & 15 & 20 \\
\hline 75 & 17 & 10 & 5 & 12 & 18 \\
\hline 50 & 15 & 8 & 4 & 10 & 10 \\
\hline 25 & 10 & 5 & 2 & 4 & 5 \\
\hline 10 & $2 *$ & $3 *$ & 0 & 4* & 5* \\
\hline 5 & $1 *$ & $2 *$ & 0 & $2 *$ & $4^{*}$ \\
\hline 1 & 0 & 0 & 0 & 0 & 0 \\
\hline 0.1 & 0 & 0 & 0 & 0 & 0 \\
\hline
\end{tabular}

* Fungistatic effect

The toxicity of MEA for yeasts (Table 4) suggests that various concentrations have different effects on various yeasts. For Rhodosporidium diobovatum strains undiluted MEA solutions form a $10 \mathrm{~mm}$ fungicidal zone while for lower concentrations $(50$ and $70 \%)$ the zones were 5 and $13 \mathrm{~mm}$, respectively. The MEA concentrations lower than $25 \%$ have no effect on Rhodosporidium diobovatum strain yeasts. The MEA concentrations lower than $10 \%$ have no influence on the growth of the investigated yeasts (Table4).

Table 4. Assessment of MEA tars toxicity to various yeasts species

\begin{tabular}{|c|c|c|c|c|c|}
\hline \multirow{2}{*}{$\begin{array}{c}\text { Concentration } \\
\%\end{array}$} & \multicolumn{5}{|c|}{ Zone of inhibition, mm } \\
\cline { 2 - 6 } & $\begin{array}{c}\text { Rhodosporium } \\
\text { diobovatum }\end{array}$ & $\begin{array}{c}\text { Aureobasitium } \\
\text { pullulans }\end{array}$ & $\begin{array}{c}\text { Rhodotorula } \\
\text { rubra }\end{array}$ & $\begin{array}{c}\text { Candida } \\
\text { lipolitica }\end{array}$ & $\begin{array}{c}\text { Geotrihum } \\
\text { fermentans }\end{array}$ \\
\hline 100 & $10^{*}$ & $10^{*}$ & $8^{*}$ & $10^{*}$ & $15^{*}$ \\
\hline 75 & $13^{* *}$ & $9^{*}$ & $6^{*}$ & $8^{*}$ & $10^{*}$ \\
\hline 50 & $8^{* *}$ & $8^{* *}$ & 0 & $6^{*}$ & $10^{*}$ \\
\hline 25 & 0 & $6^{*}$ & 0 & $4^{*}$ & $8^{*}$ \\
\hline 10 & 0 & - & 0 & 0 & 0 \\
\hline 5 & 0 & $8^{* *}$ & 0 & 0 & 0 \\
\hline 1 & 0 & $8^{* *}$ & 0 & 0 & 0 \\
\hline 0.1 & 0 & $6^{* *}$ & 0 & 0 & 0 \\
\hline
\end{tabular}

* Fungicidal zone; ${ }^{* *}$ Fungistatic zone

\subsection{Assessment of MEA and soil mixtures}

For this purpose humus rich soil with $\mathrm{pH} 7.3$ was prepared and conditioned for 24 days at $18 \pm 0.5^{\circ} \mathrm{C}$. The $\mathrm{pH}$ was monitored and checked after 4,14 and 42 days. It was obvious that MEA solution must change the $\mathrm{pH}$ of soil. In accordance with the MEA concentration in soil the values of $\mathrm{pH}$ at the beginning of the experiment were within the interval from 9.3 to 19.7 , but after the experiment they changed to 8.4 and 9.2. In all the mixtures of MEA with soil in the experiment the values of $\mathrm{pH}$ were higher than 8 all the time during experiment. 
The dynamics of the growth of the microorganism's number suggests that the microorganisms accommodated and procreated even at high MEA concentrations $(\sim 10 \%)$ in soil. At lower concentrations $(<2.5)$ the growth of microorganisms was rather rapid and it accelerated as the concentration of MEA decreased during to its decomposition. It is obvious from the experiment of respiration (Table 5).

The respiration intensity was checked after a few first days, then after two weeks and 2 months by measurement of the evolved $\mathrm{CO}_{2}$ and was expressed in $\mathrm{mg}$ per $\mathrm{kg}$ of soil within an hour. As it is presented in Table 5, after a few first days of experiment the data from the blanc and from a 1:40 MEA mixture with soil statistically coincided, but after three days the respiration in mixture was more intensive than that in the blanc and it reached the maximum after four days (Table 5).

Table 5. Intensity of respiration of soil mixtures with MEA tars ( $\left.\mathrm{CO}_{2} \mathrm{mg} / \mathrm{kg} \cdot \mathrm{h}\right)$

\begin{tabular}{|c|c|c|c|c|c|c|}
\hline \multirow{2}{*}{$\begin{array}{c}\text { Test } \\
\text { conditions }\end{array}$} & \multicolumn{6}{|c|}{ Measurement of intensity of respiratory after: } \\
\cline { 2 - 7 } & 1 days & 2 days & 3 days & 4 days & 2 weeks & 2 month \\
\hline Blanc & $1.4 \pm 0.5$ & $1.8 \pm 0.3$ & $2.0 \pm 0.04$ & $1.5 \pm 0.2$ & $1.4 \pm 0.5$ & $1.3 \pm 0.3$ \\
\hline $1: 40$ & $1.4 \pm 0.2$ & $1.6 \pm 0.1$ & $2.2 \pm 0.2$ & $9.0 \pm 1.0$ & $4.0 \pm 1.1$ & $5.7 \pm 1.3$ \\
\hline $1: 20$ & $0.9 \pm 0.2$ & $0.3 \pm 0.1$ & $0.6 \pm 0.1$ & $1.0 \pm 0.3$ & $3.8 \pm 0.7$ & $2.4 \pm 0.6$ \\
\hline $1: 10$ & $0.1 \pm 0.02$ & $0.04 \pm 0.01$ & $0.2 \pm 0.1$ & $0.5 \pm 0.1$ & $1.2 \pm 0.2$ & $3.6 \pm 0.9$ \\
\hline
\end{tabular}

Evaluation of MEA in soil toxicity on plants by measurements of seed germination (Table 6) showed that when the concentration of MEA in soil is lower than $\sim 1 \%$ (it means about 100 $\mathrm{g} / \mathrm{kg}$ ) the seed germination energy is high (70-90\%) and germination reaches $65 \%$. Therefore, for detoxification of low MEA concentrations in soil it is possible to use plants as a more powerful bioremediation tool.

Table 6. Percentage of viable and germinated seeds in soils with a different concentration of $M E A$

\begin{tabular}{|c|c|c|c|c|c|}
\hline Proportion of & \multirow{2}{*}{$\begin{array}{c}\text { Concentration } \\
\text { MEA and soil }\end{array}$} & \multicolumn{2}{|c|}{ Ray } & \multicolumn{2}{|c|}{ Wheat } \\
\cline { 3 - 6 } & $\%$ & $\begin{array}{c}\% \text { of } \\
\text { viable }\end{array}$ & $\begin{array}{c}\% \text { of } \\
\text { germinated }\end{array}$ & $\begin{array}{c}\% \text { of } \\
\text { viable }\end{array}$ & $\begin{array}{c}\% \text { of } \\
\text { germinated }\end{array}$ \\
\hline Blanc & 0 & $98 \pm 7$ & $98 \pm 7$ & $96 \pm 6$ & $96 \pm 6$ \\
\hline $1: 1000$ & 0.1 & $63 \pm 8$ & $59 \pm 6$ & $60 \pm 6$ & $46 \pm 5$ \\
\hline $1: 500$ & 0.2 & $80 \pm 6$ & $80 \pm 4$ & $98 \pm 9$ & $94 \pm 9$ \\
\hline $1: 200$ & 0.5 & $71 \pm 12$ & $61 \pm 3$ & $66 \pm 6$ & $54 \pm 3$ \\
\hline $1: 140$ & 0.7 & $69 \pm 5$ & $63 \pm 5$ & $94 \pm 10$ & $67 \pm 3$ \\
\hline $1: 120$ & 0.8 & $49 \pm 3$ & $24 \pm 3$ & $56 \pm 5$ & $31 \pm 3$ \\
\hline $1: 100$ & 1.0 & $56 \pm 7$ & $35 \pm 2$ & $73 \pm 6$ & $50 \pm 3$ \\
\hline $1: 80$ & 1.2 & $8 \pm 3$ & $4 \pm 2$ & $60 \pm 9$ & $27 \pm 4$ \\
\hline $1: 60$ & 1.7 & $6 \pm 0.2$ & 0 & $4 \pm 0.3$ & 0 \\
\hline
\end{tabular}

Recommendations for detoxification of spent MEA solutions

It is recommended to prepare a mixture of a spent MEA solution and a soil containing humus and peat. The concentration of MEA in such a mixture should not be higher than $15-20 \mathrm{~g} / \mathrm{kg}$. Such a substrate should be spread on the flat hydro-isolated surface as a $30-40 \mathrm{~cm}$ thick layer. For the sewage water there should be a special container. In such a layer pH should be kept within the interval of $\mathrm{pH} 6.5-7.5$ by means of acidic peat $(\mathrm{pH} \mathrm{3-6)}$ and the basic solution of $\mathrm{NaOH}$. The substrate should be fertilized every 20 days by phosphoric and potassium salts. 
There is no need for a nitrogen manure because MEA contains enough nitrogen for soil microorganisms. The substrate should be moistened up to $65 \%$ of soil water content. Aeration of the substrate is performed by means of a rearer 2-3 times per week when the temperature of the substrate is $20-27{ }^{\circ} \mathrm{C}$ or $1-2$ times per week in spring or autumn when the temperature is $13-20{ }^{\circ} \mathrm{C}$.

The organic substances in the substrate are decomposed and utilized as a manure by such soil microorganisms groups as Arthrobacter, Bacillus, Bacterium, Corynebacterium, Flaebobatrium, Mycobacterium. Pseudomonas, Rhodococcus, Aspergilus, and Penicillium. Candida lipolytica and Trichoderma haranum show especially intensive MEA products digestion. For fast utilization of MEA in the soil substrate the concentration of the suspension of microorganism should be within the range of $10^{8}-10^{9}$ cells $/ \mathrm{ml}$ and about 31 of the suspension is used for a square meter of a substrate layer.

When the concentration of MEA in the soil substrate is as low as 6-7 $\mathrm{g} / \mathrm{kg}$ it means that vascular plants such as winter rye (Secale cereale) or bushgrass (Calamagrostis epigeo) or osier willow (Salix vininealis) $[9,10]$ my be implanted for finishing of the bioremediation. By and large the whole process of MEA detoxification takes about one hundred days.

\section{CONCLUSIONS}

1. Tars of MEA at concentrations of $5 \%$ to $25 \%$ have influence on some bacteria: fungistatical influence at $5 \%$ and fungicidal influence at $25 \%$.

2. Tars of MEA at concentrations up to $10 \%$ did not influence the growth of yeast, but at concentrations higher than $25 \%$ they are fungicidal.

3. The toxicity of MEA tars on vascular plants (rye, wheat) seed germination and germination energy is moderate at concentrations of $6-7 \mathrm{~g} / \mathrm{kg}$ in the detoxification substrate.

4. Various acidity peats' can be used for mixing of soil and MEA tars in detoxification substrate.

5. A new detoxification method is proposed. It involves mixing of the MEA tar at a concentration of $15 \mathrm{~g} / \mathrm{kg}$ with soil and exposing it to aerobic bacteria to reduce the concentrations to $6-7 \mathrm{~g} / \mathrm{kg}$ and then use vascular plants for the last stage of detoxification.

\section{ACKNOWLEDGEMENTS}

This study was financially supported by stock company AB "ACHEMA". Their assistance and samples are gratefully acknowledged.

\section{REFERENCIES}

[1] Khitrin, S.V., Fuks, S. L., Deviaterikova, S.V., 2002. Issledovanie sostava i vozmozhnostei primenenija otkhodov monoetanolaminovoi ochistki vodoroda ot uglekislogo gaza (Investigation of the composition and possibilities to use the wastes of hydrogen purification from carbon dioxide by monoethanolamine). Zhurnal prikladnoi khimii 75(1), 63-66 (in Russian).

[2] Baco, T. R., Dupart, M. S., Rooney, P. S., 1998. Role of Oxygen in Alkanoamine Degradation. Hydrocarbon Processing 109-113.

[3] Chi, S., et al. 2001. Oxidative Degradation of Monoethanolamine, First National Conference on Carbon Sequestration. Washington, AS, May 14-17.

[4] Tereshenko, L. Ja., et al. 1995. Filtr dla ochistki rastvora MEA ot smolistykh veshestv i ikh primenenie (Filter for purification of MEA solutions from tars and their usage) Pat.RU 2046629 (in Russian). 
[5] Utkin, V.V. et al. 1994. Sredstvo dla chistki izdelii iz kozhi (Agent for leather cleaning). Pat. RU 2021311 (in Russian).

[6] Jankovskii, H.A. et al. 1999. Kleevaja kompozicija (Composition of a glue). Pat. RU 2149882 (in Russian).

[7] Tugolukov, A. B. et al. 2002. Sposob utilizacii otrabotannogo pastvora MEA (Method for utilization of waste solutions of MEA). Pat. RU 22223943 (in Russian).

[8] Hirzel, S. 1996. Monoethanolamine. BVA Report. German Chemical Society, 1-18.

[9] Snarskis, P. 1954. Vadovas Lietuvos TSR augalams pažinti (Compendium of Plants of Lithuanian SSR) Vilnius (in Lithuanian).

[10] Smaliukas, D. 1996. Lietuvos gluosniai (Willows of Lithuania) Vilnius (in Lithuanian). 